Open Access Full Text Article

\title{
Response to Burnout as a State: Random-Intercept Cross-Lagged Relationship Between Exhaustion and Disengagement in a I0-Day Study [Letter]
}

This article was published in the following Dove Press journal: Psychology Research and Behavior Management

\author{
Robert I Block (D) \\ Heather L Bair ${ }^{1,2}$ \\ James F Carillo id \\ 'Department of Anesthesia, Roy J. and \\ Lucille A. Carver College of Medicine, \\ University of lowa, lowa City, IA, USA; \\ ${ }^{2}$ College of Nursing, University of lowa, \\ lowa City, IA, USA
}

\section{Dear editor}

We thank Basinska and Gruszczynska ${ }^{1}$ for their interesting and sophisticated analyses of relationships between exhaustion and disengagement as assessed by the Oldenburg Burnout Inventory $(\mathrm{OLBI})^{2}$ over 10 consecutive workdays. In a study not cited in their article, we recently examined the relationship between exhaustion and disengagement in an academic anesthesia department. ${ }^{3}$ Our study involved a one-time administration of the OLBI. We noted that the mean for exhaustion exceeded that for disengagement, ie, burnout symptoms were reflected more in exhaustion than disengagement. The means \pm standard deviations were $2.52 \pm 0.51$ for exhaustion, $2.27 \pm 0.52$ for disengagement, and $0.25 \pm 0.42$ for their difference, $\mathrm{t}(129)=6.68$ by paired $t$-test, effect size (Cohen's $d)=0.59$. Moreover, higher exhaustion means were generally associated with higher disengagement means, $r=0.66$ by Pearson correlation coefficient. For comparison with our and other studies (which commonly involve one-time administrations), it would be informative if Basinska and Gruszczynska would report a paired $t$-test and $\mathrm{r}$ for their first day of ratings, indicating the significances of the difference between exhaustion and disengagement and of the correlation between these two components of burnout. This information may be available or derivable from the results they report, but is not obvious (to us, at least). None of the studies in our literature review ${ }^{3}$ - which was based on a PubMed search and, therefore, captured primarily, but not exclusively, health-care related samples of staff and students - tested the statistical significance of the difference between exhaustion and disengagement, as we did. This seemed surprising to us, considering the centrality of the distinction between exhaustion and disengagement to the conceptual model underlying the OLBI. ${ }^{2}$ Although it is clear that exhaustion and disengagement are intended to be compared in this model, ${ }^{2}$ as far as we know, the OLBI development process and subsequent studies have not established expected values of exhaustion and disengagement (or their difference), for any large, broadly representative normative population. Our study and literature review ${ }^{3}$ were intended, in part, to highlight the gap in knowledge concerning differences in exhaustion and disengagement. We think that filling this gap in our study and subsequent studies, such as that of Basinska and Gruszczynska, ${ }^{1}$ and trying to understand why there has been pronounced variability in past studies with respect to the direction and magnitude of differences between exhaustion and disengagement, ${ }^{3}$ might enhance the utility of the OLBI compared to other questionnaires for assessing burnout. 


\section{Disclosure}

The authors report no conflicts of interest in this communication.

\section{References}

1. Basinska BA, Gruszczynska E. Burnout as a state: random-intercept cross-lagged relationship between exhaustion and disengagement in a 10-day study. Psychol Res Behav Manag. 2020;13:267-278. doi:10. 2147/PRBM.S244397
2. Demerouti E, Bakker AB, Nachreiner F, Schaufeli WB. The Job Demands-Resources model of burnout. J Appl Psychol. 2001;86 (3):499-512. doi:10.1037/0021-9010.86.3.499

3. Block RI, Bair HL, Carillo JF. Is exhaustion more sensitive than disengagement to burnout in academic anesthesia? A study using the Oldenburg Burnout Inventory. Psychol Rep. 2019. doi:10.1177/ 0033294119856560

Dove Medical Press encourages responsible, free and frank academic debate. The content of the Psychology Research and Behavior Management 'letters to the editor' section does not necessarily represent the views of Dove Medical Press, its officers, agents, employees, related entities or the Psychology Research and Behavior Management editors. While al reasonable steps have been taken to confirm the content of each letter, Dove Medical Press accepts no liability in respect of the content of any letter, nor is it responsible for the content and accuracy of any letter to the editor.

Psychology Research and Behavior Management

Dovepress

\section{Publish your work in this journal}

Psychology Research and Behavior Management is an international, peer-reviewed, open access journal focusing on the science of psychology and its application in behavior management to develop improved outcomes in the clinical, educational, sports and business arenas. Specific topics covered in the journal include: Neuroscience, memory and decision making; Behavior modification and management; Clinical applications; Business and sports performance management; Social and developmental studies; Animal studies. The manuscript management system is completely online and includes a very quick and fair peer-review system, which is all easy to use. Visit http://www. dovepress.com/testimonials.php to read real quotes from published authors. 